\title{
COMMONWEALTH
}

A Journal of Pennsylvania Politics and Policy

EDITOR-IN-CHIEF J. Wesley Leckrone, Widener University

MANAGING EDITOR Michelle J. Atherton, Temple University

BOOK REVIEW EDITOR/

ASSOCIATE EDITOR Thomas J. Baldino, Wilkes University

ASSOCIATE EDITORS Christopher Borick, Muhlenberg College Paula A. Duda Holoviak, Kutztown University Joseph P. McLaughlin, Jr., Temple University

\section{EDITORIAL ADVISORY}

BOARD Bruce Caswell, Rowan University

Beverly A. Cigler, Pennsylvania State University, Harrisburg

Richardson Dilworth, Drexel University

John J. Kennedy, West Chester University

John Kincaid, Lafayette College

Joseph Marbach, Georgian Court University

David Y. Miller, University of Pittsburgh

Megan Mullin, Duke University

Richard A. Stafford, Carnegie Mellon University

COPY EDITOR Barbara Crawford

EDITORIAL ASSISTANTS Monica Gaydos, University of Pittsburgh

Catherine Long, Widener University

FOUNDING EDITOR

EMERITUS Donald G. Tannenbaum, Gettysburg College

EDITORS EMERITUS Thomas J. Baldino, Wilkes University Gerard J. Fitzpatrick, Ursinus College 


\section{The Pennsylvania Political Science Association}

ounded in 1939, the Pennsylvania Political Science Association (PPSA) is the nation's oldest state political science association. Its mission has always been to promote scholarship, research, and the exchange of ideas within the Pennsylvania community of political scientists. PPSA draws its membership principally from the political science and public administration faculties of Pennsylvania's public and private colleges and universities but also includes government professionals and faculty members from surrounding states.

PPSA's annual conference includes dozens of panelists covering a wide variety of subjects. While university faculty compose the vast majority of participants, legislators, legislative staff, executive officials, and undergraduates also have participated. For more information on the activities of PPSA and membership rates, please visit the Association's website at http://www.papolisci.org/. 
THE PENNSYLVANIA POLITICAL SCIENCE ASSOCIATION

OFFICERS AND EXECUTIVE COUNCIL

$2017-2018$

PRESIDENT

Steven Peterson

Pennsylvania State

University, Harrisburg
FIRST VICE PRESIDENT

A. Lanethea Mathews-Schultz Michael Greenberg Muhlenberg College

Shippensburg University

\author{
TREASURER \\ Steven B. Lem \\ Kutztown University
}

SECRETARY

Paula A. Duda Holoviak

Kutztown University

EXECUTIVE COUNCIL

2015-2018

Michelle J. Atherton

Temple University

Heather Frederick

Slippery Rock University
2016-2019

Joseph P. McLaughlin, Jr.

Temple University

Jennie Sweet-Cushman

Chatham College
$2017-2020$

Justin DePlato

Robert Morris University

Sarah Niebler

Dickinson College

\section{EX OFFICIO MEMBERS}

IMMEDIATE PAST PRESIDENT

Christopher Borick

Muhlenberg College
PAST PRESIDENT

Brooke Harlowe

Lock Haven University
PAST PRESIDENT

Stanley Berard

Lock Haven University

EDITORIAL STAFF OF COMMONWEALTH:

A Journal of Pennsylvania Politics and Policy

EDITOR-IN-CHIEF

J. Wesley Leckrone

Widener University

EDITOR EMERITUS

Gerard J. Fitzpatrick

Ursinus College
BOOK REVIEW EDITOR \& EDITOR EMERITUS

Thomas J. Baldino

Wilkes University

FOUNDING EDITOR EMERITUS

Donald G. Tannenbaum

Gettysburg College 


\section{Pennsylvania Policy Forum}

OMMONWEALTH collaborates with the Pennsylvania Policy Forum to plan special issues and attract high-quality content to the journal. The Forum is a consortium of faculty members and academic and policy institute leaders from Pennsylvania colleges and universities who share an interest in generating ideas, analyses, and symposiums that might prove useful to citizens, elected officials, and civic leaders in addressing major issues confronting the Commonwealth and its local governments. As educators who have helped train students for careers in public policy, members also share an interest in helping to improve the skills, knowledge, and tools of leaders in the public and civic sectors.

Members of the Forum have expertise in public policy analysis as well as a wide range of substantive issues, including but not limited to education, transportation and public infrastructure, economic development, agriculture, energy, elections, water policy and the environment, health care, social policy, urban development, emergency management, information technology, public finance, and constitutional law. Members also share an interest in improving both the policy process itself and the institutional structures through which issues and problems are addressed.

Forum members have contributed to public policy debates in Pennsylvania, and a number have also served in state and local government and in nonprofit and civic organizations that engage in policy development and implementation. Some members of the Forum are associated with other academic and public policy-related organizations, but the Forum itself is independent of these relationships and has no formal connections to any government entity. Members obviously benefit from the intellectual resources and environments of their universities, but unless otherwise indicated, they do not act on behalf of their institutions when they sponsor Forum projects. The premise of the Forum is that through the consortium, members can jointly develop and sponsor nonpartisan research, symposiums, and education and training programs of value to elected officials, civic leaders, and the public and thereby enhance their ability to contribute to more intelligent and informed policymaking. 


\section{PENNSYLVANIA POLICY FORUM MEMBERSHIP (2018)}

Theodore R. Alter, professor of agricultural, environmental, and regional economics, Pennsylvania State University

Michelle J. Atherton, associate director, Institute for Public Affairs, Temple University

Thomas J. Baldino, professor of political science, Wilkes University

Michael Cassidy, adjunct instructor of political science, Temple University

Beverly A. Cigler, professor of public policy and administration, Pennsylvania State University, Harrisburg

Richardson Dilworth, professor of political science and director of the Center for Public Policy, Drexel University

Michael R. Dimino, Sr., associate professor of law, Widener University Commonwealth Law School

(Chair) Paula A. Duda Holoviak, professor of political science, Kutztown University

Mark Alan Hughes, professor of practice at PennDesign and faculty director of the Kleinman Center for Energy Policy, University of Pennsylvania

John J. Kennedy, professor of political science, West Chester University

Michael King, adjunct professor, Albright College and Temple University, and associate professor, Pennsylvania State University (retired)

Robin Lauermann, professor of politics and international relations, Messiah College

J. Wesley Leckrone, associate professor of political science, Widener University

Nelson Lim, executive director, Fels Institute of Government, University of Pennsylvania

(Vice Chair) Joseph P. McLaughlin, Jr., director of the Institute for Public Affairs, Temple University

David Y. Miller, associate professor and director of the Innovation Clinic, Graduate School of Public and International Affairs, University of Pittsburgh

Randall M. Miller, professor of history, St. Joseph's University

Theresa Miller, director, Institute of Politics, University of Pittsburgh

Joseph Sabino Mistick, associate professor of law, Duquesne University School of Law

Richard A. Stafford, distinguished service professor of public policy, Heinz College, Carnegie Mellon University

David B. Thornburgh, executive director of the Committee of Seventy

Craig Wheeland, associate vice president for academic affairs and professor, Villanova University 


\section{Contents}

Volume 20, Numbers 2-3 | 2018 | ISSN 2469-7672

\section{EDITORS' NOTE}

- The Heroin and Opioid Epidemic: Pennsylvania's Statewide Disaster Emergency | Mark A. Nordenberg and Janice L. Pringle, Special Issue Editors

\section{ARTICLES}

- COMMONWEALTH Forum: Law Enforcement in the Twenty-First Century: Partnering to Combat the Opioid Overdose Epidemic | Josh Shapiro

- Drug Overdoses in Pennsylvania: Measuring, Tracking, and Forecasting the Epidemic | Donald S. Burke and Jeanine M. Buchanich

n Prevention of Opioid Addiction | Ralph E. Tarter, Gerald Cochran, and Maureen Reynolds

- Treatment, Overdose, and Finding the Road to Recovery | Michael T. Flaherty

- Forgotten but Not Gone: The Impact of the Opioid Epidemic and Other Substance Use Disorders on Families and Children | Dennis C. Daley, Erin Smith, Daniel Balogh, and Jodi Toscolani

- Physician Responses to the Opioid Epidemic in the Context of Population-Based Pain and Opioid Care | Ajay D. Wasan

- The Pennsylvania Prescription Drug Monitoring Program: Reducing the Misuse of Prescription Opioids | Lynn S. Mirigian, Laura A. Hendrick, Janice L. Pringle, and Michael A. Zemaitis

- The Role of Community Coordinated Efforts in Combating the Opioid Overdose Crisis: The Pennsylvania Opioid Overdose Reduction Technical Assistance Center | Lynn S. Mirigian, Marco F. Pugliese, Janice L. Pringle, and Monica F. Gaydos 